\title{
Validated RP- HPLC Method for the Assay of Etoricoxib (A Non-Steroidal Anti-Inflammatory Drug) in Pharmaceutical Dosage Forms
}

\author{
SRINIVASU TOPALLI*1* T. G. CHANDRASEKHAR ${ }^{1}$ AND M. MATHRUSRI \\ ANNAPURNA ${ }^{2}$ \\ ${ }^{1}$ Ranbaxy Research Laboratories Ltd. Gurgaon, Haryana, India. \\ ${ }^{2}$ Department of Pharmaceutical Analysis and Quality Assurance, GITAM Institute of \\ Pharmacy, GITAM University, Visakhaptanam, India
}

*Corresponding author. E-mail: srinivasu.topalli@gmail.com

srinivasut@yahoo.com

\begin{abstract}
A simple, accurate, sensitive and reproducible reverse phase high performance liquid chromatographic method has been developed for the quantitative determination of Etoricoxib in pharmaceutical dosage forms. The assay was performed on Hypersil ODS C-18 (250 x $4.6 \mathrm{~mm}$., $5 \mu \mathrm{m}$ particle size) column using acetonitrile and potassium dihydrogen phosphate buffer $(\mathrm{pH} 4.2)(46: 54 \% \mathrm{v} / \mathrm{v})$ as mobile phase with UV detection at $280 \mathrm{~nm}$ (flow rate $1.2 \mathrm{ml} / \mathrm{min}$ ). Bromhexine was used as an internal standard. Quantization was achieved by measurement of the peak area ratio of the drug to the internal standard. The limit of detection (LOD) and the limit of quantification (LOQ) were $0.0704 \mu \mathrm{g} \mathrm{ml}^{-1}$ and $0.2134 \mu \mathrm{g} \mathrm{ml}^{-1}$ respectively. Each analysis required no longer than 10 minutes. The calibration curve was linear over the concentration range from $0.5-85.0 \mu \mathrm{g} \mathrm{ml}^{-1}$. The retention times of Etoricoxib and Bromhexine were found to be 3.083 and 7.631 minutes respectively. The proposed method was validated according to the ICH guidelines and can be used successfully to analyse marketed formulations.
\end{abstract}

Key words: Etoricoxib, Bromohexine, Acetonitrile, RP-HPLC, ICH.

\section{Introduction}

Etoricoxib $^{1}$ (ETC) (Figure 1) is a new non-steroidal anti-inflammatory drug (NSAID) which is chemically 5-chloro-6'-methyl-3-[4-(methylsulphonyl) phenyl]-2,3'-bipyridine. It inhibits the synthesis of prostaglandins by inhibiting the activity ${ }^{2-3}$ of the enzyme, cyclooxygenase- 2 . It has highest COX-2 selectivity and better safety profile. It is active at low dose and has less gastric toxicity ${ }^{4}$. 


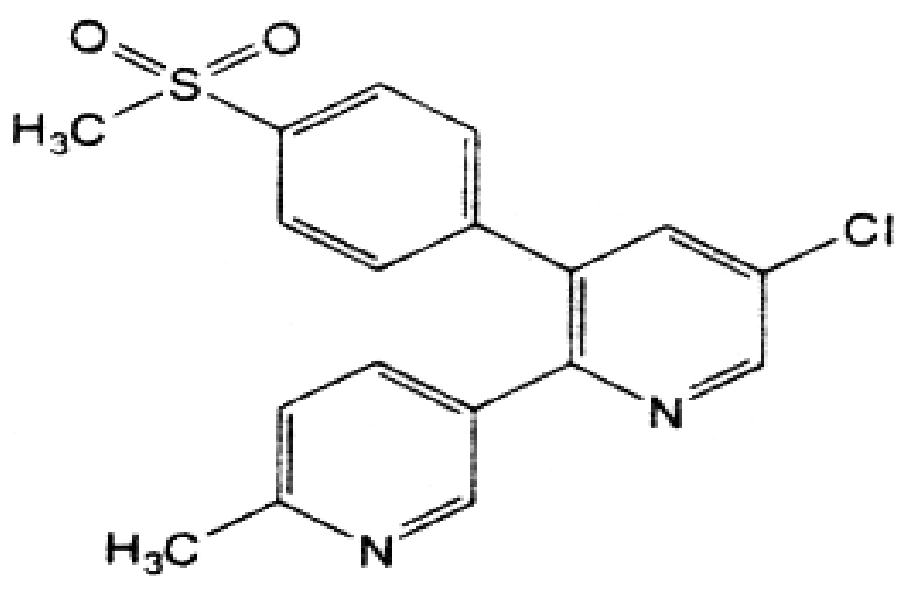

Figure 1. Chemical Structure of Etoricoxib (ETC).

Etoricoxib is preferred over conventional NSAIDs as they may lead to serious gastrointestinal complications such as ulcer, severe bleeding and perforation resulting in hospitalization and even death ${ }^{5}$. It is mainly used for the osteoarthritis, rheumatoid arthritis and acute gouty arthritis ${ }^{6-8}$. ETC administered as a tablet is rapidly and completely absorbed and available; the absolute bioavailability is estimated to be $100 \%$ and is metabolized extensively via oxidation 6 ' -methyl hydroxylation and 1 '-N-oxidation and the metabolites are excreted largely in the urine ${ }^{9}$. A high fat meal decreased the rate of absorption without effecting the extent of absorption of ETC; therefore it can be dosed irrespective of food. The dose proportionality of oral ETC in healthy volunteers as well as the Single- and MultipleDose Pharmacokinetics of ETC was also studied ${ }^{10-11}$.

ETC was determined in human plasma ${ }^{12-15^{\circ}}$ using HPLC-MS/MS. HPLC ${ }^{16-17}$, spectrophotometric $^{18}$ and capillary zone electrophoresis ${ }^{19}$ were also reported for the determination of ETC. ETC was determined in serum and synovial fluid of patients with inflammatory arthritis by ultra performance liquid chromatography-inductively coupled ${ }^{20}$ plasma mass spectroscopy and quadrupole time-of-flight mass spectrometry and also by HPTLC $^{21}$ method using chloroform: methanol : toluene $(4: 2: 4 \mathrm{v} / \mathrm{v})$ mobile phase. Matthews et $\mathrm{al}^{22}$ isolated and characterized the photolytic products using HPLC-UV-fluorescence, HPLC-MS/MS, NMR and HPLC-NMR showing that Etoricoxib undergoes a photocyclization reaction when irradiated with UV light $(254 \mathrm{~nm})$ leading to the formation of two major isometric photocyclazation products. In the present study the authors proposed a relatively simple, reliable reproducible RP-HPLC method for the determination of Etoricoxib in pharmaceutical dosage forms and validated as per the $\mathrm{ICH}^{23}$ guidelines.

\section{Experimental}

\section{Chemicals and Reagents}

Pharmaceutical grade Etoricoxib (ETC) drug was supplied as gift sample from Ranbaxy Research Laboratories Ltd. (Haryana, India). Etoricoxib is available in India as tablets with brand names ETOZOX (Cipla), KINGCOX (Cadila HC) and ETROBAX (Ranbaxy) (60, 90 and $120 \mathrm{mg}$ per tablet) and were purchased from the local market. HPLC grade acetonitrile (Merck) was used and all other chemicals were of analytical grade. 


\section{Instrument used}

Quantitative HPLC was performed on a binary gradient HPLC with Shimadzu LC-10AT and LC-10AT VP Series HPLC pumps, with a $20 \mu \mathrm{L}$ sample injection loop (manual) and SPD 10AT series UV-Visible detector. The output signal was monitored and integrated using Shimadzu Class-VP Version 6.12 SP1 Software. A Hypersil ODS $\mathrm{C}_{18}$ column $(250 \mathrm{~mm} \times$ $4.6 \mathrm{~mm}, 5 \mu \mathrm{m}$ ) was used for separation. Afcoset analytical electronic balance was used.

\section{Selection of Mobile Phase}

The mobile phase acetonitrile: potassium dihydrogen phosphate buffer $(0.05 \mathrm{M})$ was prepared $46: 54 \% \mathrm{v} / \mathrm{v}$ at a flow rate of $1.2 \mathrm{ml} /$ min produces peaks with good resolution for Etoricoxib and Bromohexine (Internal standard).

\section{Preparation of standard drug solution}

Stock solution of Etoricoxib (ETC) $(1 \mathrm{mg} / \mathrm{ml})$ was prepared by dissolving $25 \mathrm{mg}$ of Etoricoxib in $25 \mathrm{ml}$ of volumetric flask containing $10 \mathrm{ml}$ of mobile phase. The solution was sonicated for about 20 minutes and then made up to volume with mobile phase.

Working standard solutions of Etoricoxib were prepared by suitable dilution of the stock solution with mobile phase. Similarly stock solution of internal standard was prepared by dissolving $25 \mathrm{mg}$ of Bromohexine in $25 \mathrm{ml}$ of volumetric flask containing $10 \mathrm{ml}$ of mobile phase, sonicated for $20 \mathrm{~min}$. then made up to the volume with mobile phase.

\section{Linearity}

A series of standard solutions of Etoricoxib were prepared by taking suitable aliquots of drug solution $\left(0.5-85 \mu \mathrm{g} \mathrm{mL}^{-1}\right)$ from the stock solution and spiked with internal standard solution (Bromohexine, IS) $\left(10 \mu \mathrm{g} \mathrm{mL}^{-1}\right)$ and the volume was made up to $10 \mathrm{ml}$ with mobile phase in a $10 \mathrm{ml}$ volumetric flask.

$20 \mu \mathrm{l}$ of each of ETC solution spiked with internal standard (Bromohexine, $10 \mu \mathrm{g} / \mathrm{mL}$ )) were injected into the HPLC system thrice and the chromatograms were recorded. A typical chromatogram of ETC was shown in Figure 2. The peak area obtained for ETC and the internal standard solutions were recorded and the peak area ratio of ETC to internal standard was calculated for all the solutions. A calibration curve was constructed by taking concentration of ETC on x-axis and the corresponding peak area ratios on y-axis (Figure 3).

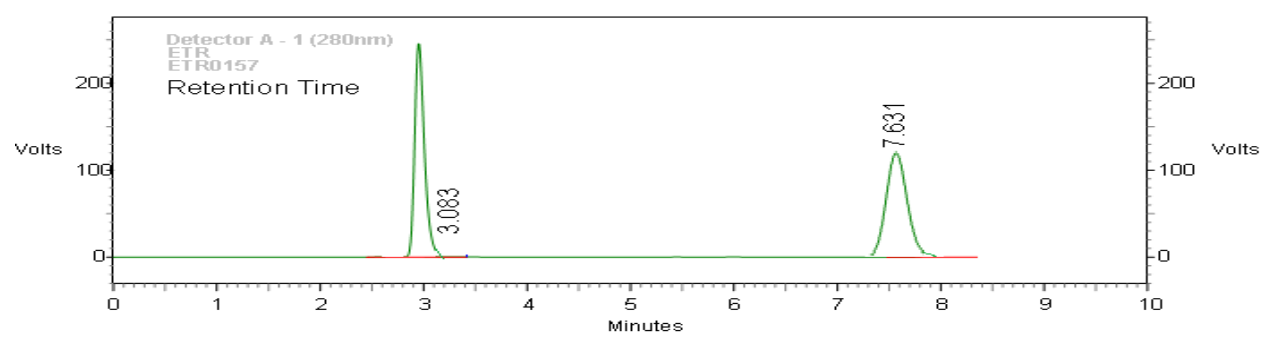

Figure 2. Representative Chromatogram of pure Etoricoxib $\left(20 \mu \mathrm{g} \mathrm{ml}^{-1}\right)(\mathrm{Rt}=3.083 \mathrm{mins})$ with Bromohexine (IS) $\left(10 \mu \mathrm{g} \mathrm{ml}^{-1}\right)(\mathrm{Rt}=7.631 \mathrm{mins})$. 


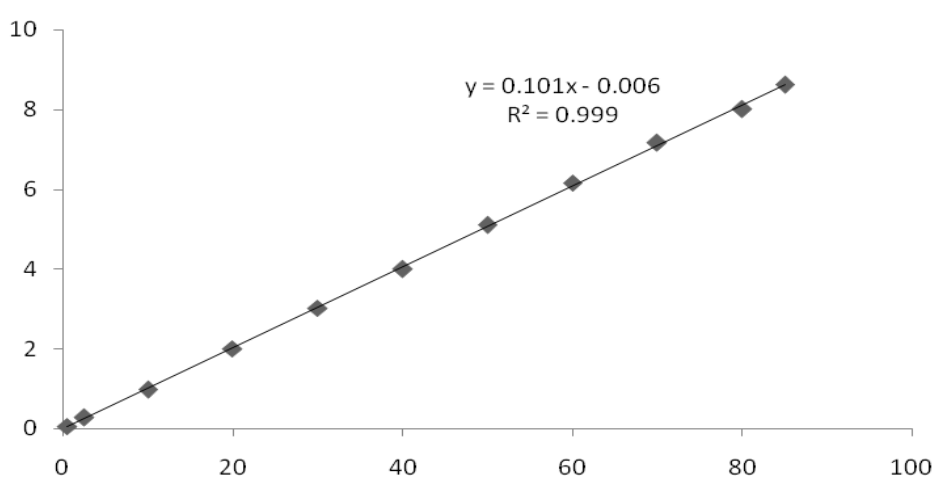

Figure 3: Calibration curve of Etoricoxib.

\section{Assay procedure for marketed formulations}

Twenty tablets were weighed, finely powdered and powder equivalent to $25 \mathrm{mg}$ of ETC was weighed accurately and extracted with mobile phase in a $25 \mathrm{ml}$ volumetric flask and sonicated. This solution was filtered through $0.45 \mu \mathrm{m}$ filter paper and diluted further with the mobile phase as per the requirement. All determinations were carried out in triplicate. $20 \mu \mathrm{l}$ of the above solutions from different brands of formulation spiked with internal standard were injected in to the HPLC system and the chromatograms were recorded (Figure 4 and 5). The assay results are shown in Table 1.

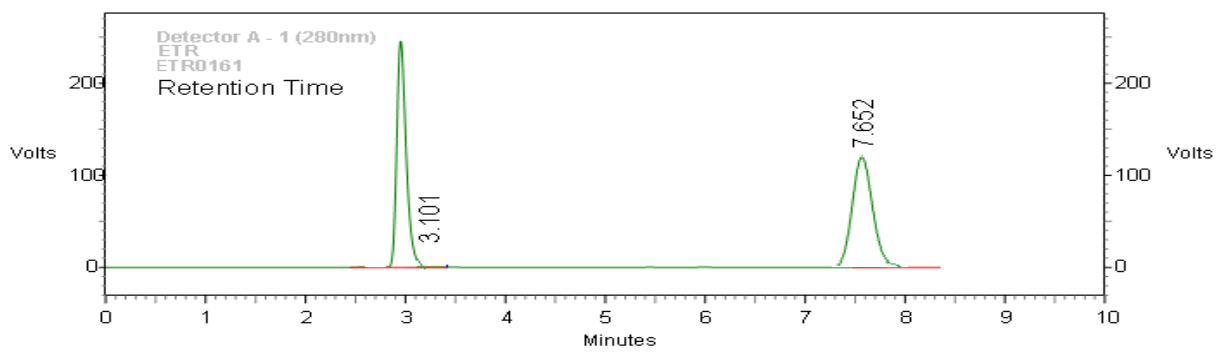

Figure 4. Representative Chromatogram of Etoricoxib Fomulation (ETOZOX - $60 \mathrm{mg}$ ) (20 $\left.\mu \mathrm{g} \mathrm{ml}^{-1}\right)(\mathrm{Rt}=3.101 \mathrm{mins})$ with Bromohexine (IS) $\left.\left(10 \mu \mathrm{g} \mathrm{ml}^{-1}\right) \mathrm{Rt}=7.652 \mathrm{mins}\right)$.

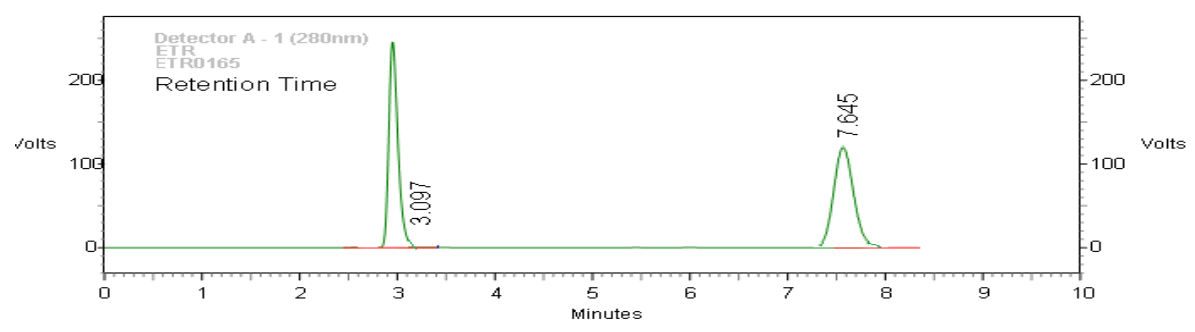

Figure 5: Representative Chromatogram of Etoricoxib Fomulation (ETROBAX - $60 \mathrm{mg}$ ) $\left(20 \mu \mathrm{g} \mathrm{ml}^{-1}\right)(\mathrm{Rt}=3.097$ mins$)$ with Bromohexine (IS) $\left(10 \mu \mathrm{g} \mathrm{ml}^{-1}\right)(\mathrm{Rt}=7.645 \mathrm{mins})$. 
Table 1: Analysis of commercial formulation.

\begin{tabular}{cccccc}
\hline & & Labeled & Amount obtained & \\
& & & & \\
S.No. & Tablet brand & beunt & broposed & $\%$ & \\
& & $(\mathrm{mg})$ & method* $(\mathrm{mg}) \pm$ & Recovery & $\%$ RSD \\
& & & SD & \\
\hline 1 & ETOZOX & 60 & $59.79 \pm 0.0156$ & 99.65 & 0.252 \\
\hline & ETROBAX & 60 & $59.84 \pm 0.0231$ & 99.73 & 0.354 \\
\hline 2 & KINGCOX & 60 & $59.68 \pm 0.0534$ & 99.47 & 0.113
\end{tabular}

*Each value is average of five determinations \pm Standard deviation (SD).

\section{Method validation}

Precision

The precision (Inter-day and Intra-day precision) was ascertained by actual determination of three replicates $(\mathrm{n}=3)$ at three different levels $(20,40$ and $60 \mu \mathrm{g} / \mathrm{ml})$ of ETC with $10 \mu \mathrm{g} / \mathrm{ml}$ internal standard. $20 \mu \mathrm{l}$ of these solutions were injected in to the HPLC system and the peak area ratio of ETC to the internal standard was noted and the percent relative standard deviation was calculated (Table 2).

Table 2: Intra-day and inter-day precision for Etoricoxib $(n=3)$.

Conc. Intra-day precision Inter-day precision

\begin{tabular}{ccccc}
\cline { 2 - 5 }$\left(\mu \mathrm{g} / \mathrm{mL}^{-1}\right)$ & Mean peak area Ratio & & Mean peak area Ratio & \\
& $($ Drug / I.S $)$ & RSD $(\%)$ & $($ Drug / I.S $) \pm \mathrm{SD}$ & RSD $(\%)$ \\
\hline 20 & $2.01331 \pm 0.00153$ & 0.0759 & $2.02131 \pm 0.00152$ & 0.0751 \\
\hline 40 & $3.99566 \pm 0.00252$ & 0.0629 & $3.89923 \pm 0.00252$ & 0.0646 \\
\hline 60 & $6.05766 \pm 00153$ & 0.0252 & $6.04676 \pm 0.01657$ & 0.274
\end{tabular}

*Each value is average of three determinations \pm Standard deviation (SD).

\section{Accuracy}

To determine the accuracy of the proposed method, recovery studies were carried out by adding different amounts $(80 \%, 100 \%, 120 \%)$ of ETC sample solutions to the pre-analyzed ETC formulation solution (within the linearity range) spiked with the internal standard and the percentage recovery values were calculated (Table 3 ). 
Table 3: Accuracy study of Etoricoxib (ETC).

\begin{tabular}{|c|c|c|c|c|c|}
\hline \multirow{2}{*}{$\begin{array}{c}\text { Spike } \\
\text { level } \\
\%\end{array}$} & \multicolumn{2}{|c|}{$\begin{array}{l}\text { Concentration } \\
\qquad\left(\mu \mathrm{g} \mathrm{ml}^{-1}\right)\end{array}$} & \multirow{2}{*}{$\begin{array}{c}\text { Total } \\
\text { conc. } \\
\left(\mu \mathrm{g} \mathrm{ml}^{-1}\right)\end{array}$} & \multirow{2}{*}{$\begin{array}{c}\% \\
\text { Recovery }\end{array}$} & \multirow[b]{2}{*}{$\%$ RSD } \\
\hline & $\begin{array}{l}\text { Pure } \\
\text { drug }\end{array}$ & Formulation & & & \\
\hline 80 & 16 & 20 & 36 & 99.48 & Mean $=99.733 \%$ \\
\hline 80 & 16 & 20 & 36 & 99.87 & $\mathrm{SD}=0.219622$ \\
\hline 80 & 16 & 20 & 36 & 99.85 & $\% \mathrm{RSD}=0.2202$ \\
\hline 100 & 20 & 20 & 40 & 98.94 & Mean $=99.523 \%$ \\
\hline 100 & 20 & 20 & 40 & 99.79 & $\mathrm{SD}=0.505799$ \\
\hline 100 & 20 & 20 & 40 & 99.84 & $\% \mathrm{RSD}=0.5082$ \\
\hline 120 & 24 & 20 & 44 & 99.97 & Mean $=99.840 \%$ \\
\hline 120 & 24 & 20 & 44 & 100.11 & $\mathrm{SD}=0.353412$ \\
\hline 120 & 24 & 20 & 44 & 99.44 & $\% \mathrm{RSD}=0.35398$ \\
\hline
\end{tabular}

\section{Results and Discussion}

Etoricoxib obeys beer's law in the concentration range of $0.5-85 \mu \mathrm{g} / \mathrm{ml}$ with regression equation $0.101 \mathrm{X}-0.006$ and correlation coefficient 0.999 . The LOD and LOQ were found to be 0.0704 and $0.2134 \mu \mathrm{g} / \mathrm{mL}$. The marketed formulations were analyzed and the percentage recovery values were in between $99.47-99.65 \%$ (Table 1). The method is precise (Table 2) as well as accurate (Table 3) as the RSD is less than 2\% The theoretical plates are found to be $5384(>2000)$ and the tailing factor is $1.1(<1.5)$.

\section{Conclusion}

The proposed method was found to be simple, precise, accurate, rapid and economical for the determination Etoricoxib in pharmaceutical dosage forms. The sample recoveries in all formulations were in good agreement with their respective label claims suggesting that no interference of excipients from the formulation. Hence this method can be conveniently adopted for routine analysis of Etoricoxib.

\section{Acknowledgements}

Authors are grateful to Ranbaxy Research Laboratories Ltd., India for providing the necessary research facilities. 


\section{References}

1. The Merck Index, An Encyclopedia of Chemical, Drugs and Biologicals, Maryadele J.O. Neil. Eds, $14^{\text {th }}$ Ed., Published by Merck Research Lab, Division of Merck and Co. Inc., Whitehouse Station, NJ, 2006, Monograph No. 3887, 662.

2. Cochrane, D J, Jarvis B and Keating G M, Drugs, 2002, 62, 2637.

3. Leclercq P and Malaise, M G, Rev. Med. Liege, 2004, 59, 345.

4. Lazzaroni M and Bianchi P G, Pharmacol. Ther., 2004, 20, 48.

5. Rubin B R, Burton R, Navarra S, Antigua J, Londono J, Pryhuber K G, Lund M, Chen E, Najarian D K, Petruschke R A, Ozturk Z E and Geba G P, Arthritis Rheum., 2004, 50, 598.

6. Ramos-Remus C R, Hunsche E, Mavros P, Querol J, Suarez R, Curr. Med. Res. Opin., 2004, 20, 691.

7. Duncan M R, and Capell H A, Int. J. Clin. Pract., 2003, 57, 315.

8. Matsumoto A K, Melian A, Mandel D R, Mcllwain H H, Borenstein D, Zhao P L, Lines C R, Gertz B J and Curtis S, J. Rheum.2002, 29, 1623.

9. Rodrigues A D, Halpin A R, Geer L A, Cui D, Catherine Z Matthews Keith M Gottesdiener, Patrick J Larson, Kenneth C Lasseter and Agrawal N G B, Drug Metabolism and Disposition, 2003, 31, 224.

10. Agrawal N G B, Porras A G, Matthews C Z, Woolf E J, Miller J L, Mukhopadhyay S, J Clin Pharmacol, 2001, 41, 1106.

11. Agarwal N G B, Porras A G, Matthews C Z et al, J Clin Pharmacol, 2003, 43, 268.

12. Braeutigam L, Nefflen $\mathrm{J} U$ and Geisslinger G, $J$ Chromatogr B Analyt Technol Biomed Life Sci., 2003, 788, 309.

13. Rose M J, Agarwal N, Woolf E J and Matuszewski B K, J. Pharm. Sci., 2002, 91, 405.

14. Werner U, Werner D, Hinz B, Lambrecht C, Brune K, Biomed Chromatogr., 2005, 19, 113.

15. Sérgio Luiz Dalmora, Liberato Brum Junior, Ricardo Machado Ferretto, Paulo Renato de Oliveira, Thiago Barth and Maximiliano da Silva Sangoi, Quím. Nova., 2008, 31, 574.

16. Hartman R, Abrahim A, Clausen A, Mao B, Crocker L S and Ge Z H, J. Liq. Chromatogr. Relat. Technol., 2003, 26, 2551.

17. Mandal U, Senthil D, Bose A, Gowda K V, Ghose A, Pal T K, Ind. J. Pharma. Sci., 2006, 68, 485.

18. Suhagia B N, Patel H M, Shah S A, Rathod I S and Marolia B P, Ind. J. Pharm. Sci., 2005, 67, 634 .

19. Sérgio Luiz Dalmora, Maximiliano da Silva Sangoi, Lucélia Magalhães da Silva, Rui Oliveira Macedo and Thiago Barth, Journal of Separation Science, 2008, 31, 169.

20. Eudoxia Diza, Lucas Settas, Paul Nikolaidis, Christopher Smith, Wilson Ian D, Journal of Pharmaceutical and Biomedical Analysis, 2009, 49, 579.

21. Shah N J, Shah S J, Patel D M, Patel N M, Ind.. J. Pharm. Edu and Res., 2006, 68, 788.

22. Matthews C Z, Subramanian R, Woolf E J, Foster N, Matuszewski B K, Pharmazie. 2004, 59, 913.

23. ICH harmonized Tripartite Guideline, Validation of Analytical Procedures: Text and Methodology Q2 (R1), 2005. 


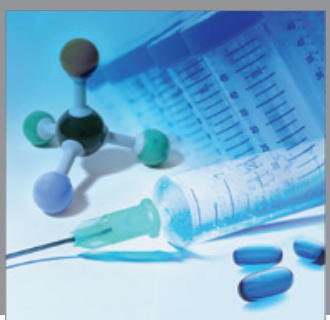

International Journal of

Medicinal Chemistry

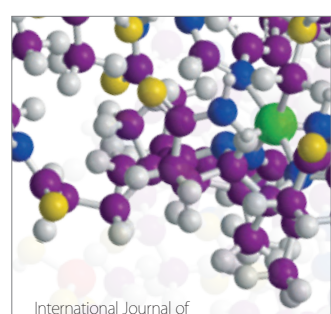

Carbohydrate Chemistry

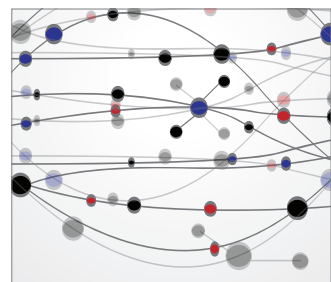

The Scientific World Journal
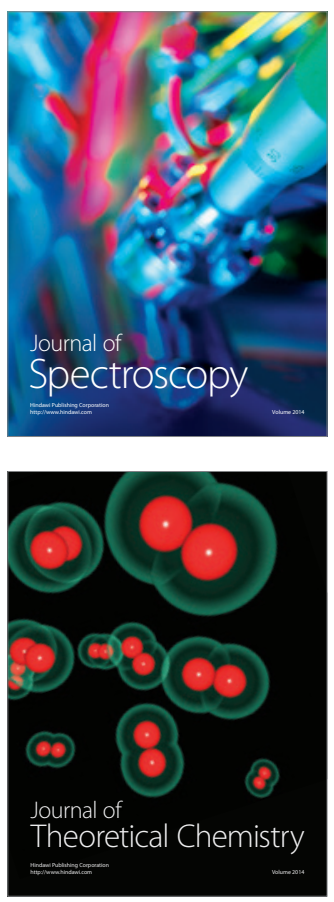
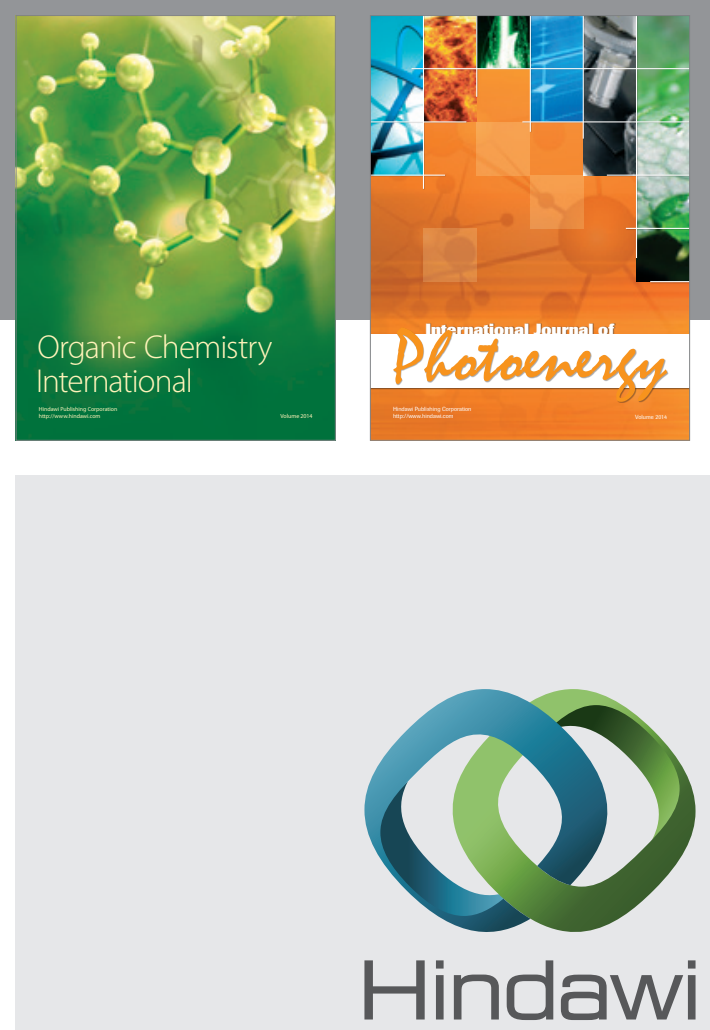

Submit your manuscripts at

http://www.hindawi.com
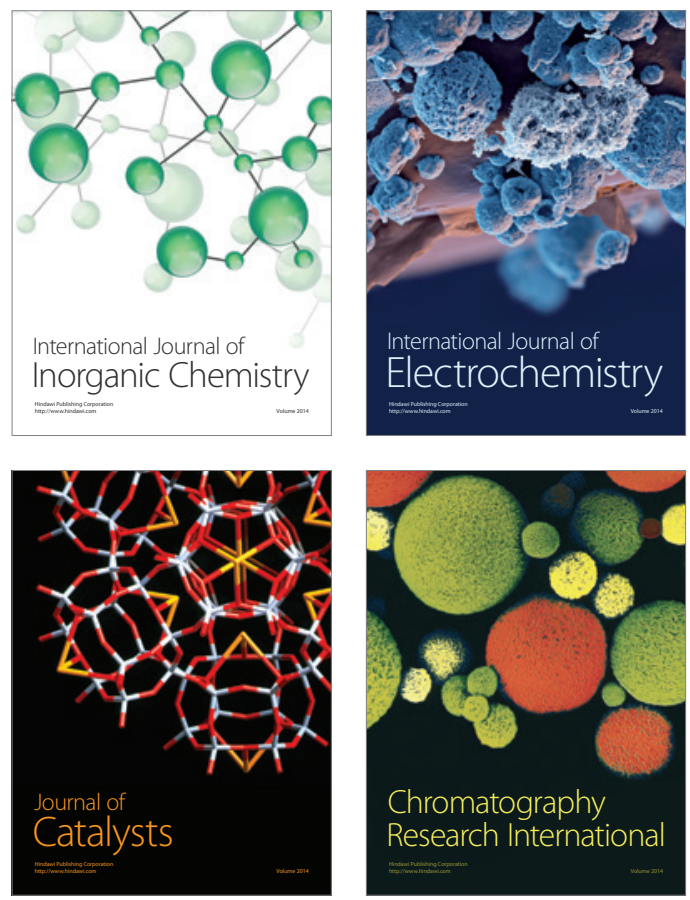
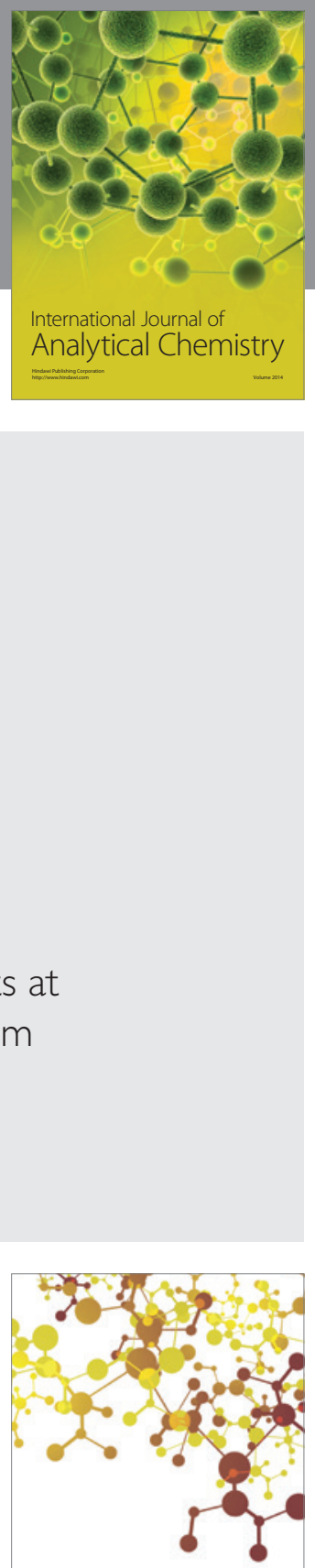

Journal of

Applied Chemistry
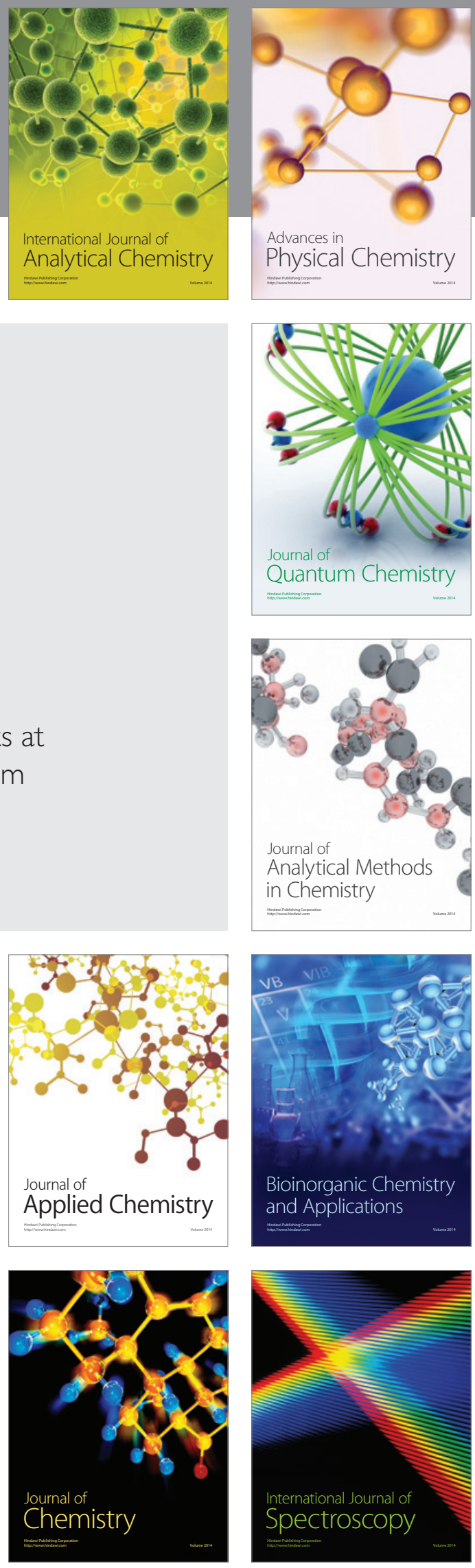